\title{
Physico-Chemical and Microbiological Analysis of Water of the "Presa De Los Patos" in the Desierto De Los Leones National Park, Mexico
}

\author{
Luis Raúl Gutiérrez-Lucas ${ }^{1 *}$, Luz María Chávez-Ramírez², Leticia Arregui1 \\ ${ }^{1}$ Departamento de Ciencias Naturales, DCNI, Universidad Autónoma Metropolitana Unidad Cuajimalpa, México City, México \\ ${ }^{2}$ Secretaría de Salud, Centro de Salud TI, Memetla, México City, México \\ Email: `gutierrez_800211@hotmail.com
}

How to cite this paper: Gutiérrez-Lucas, L.R., Chávez-Ramírez, L.M. and Arregui, L. (2017) Physico-Chemical and Microbiological Analysis of Water of the "Presa De Los Patos" in the Desierto De Los Leones National Park, Mexico. Advances in Biological Chemistry, 7, 122-138.

https://doi.org/10.4236/abc.2017.72008

Received: March 10, 2017

Accepted: April 22, 2017

Published: April 25, 2017

Copyright $\odot 2017$ by authors and Scientific Research Publishing Inc. This work is licensed under the Creative Commons Attribution International License (CC BY 4.0).

http://creativecommons.org/licenses/by/4.0/

(c) (i) Open Access

\begin{abstract}
The Desierto de los Leones National Park is a place that features recreational activities for residents and visitors to Mexico City. The Presa de los Patos (Ducks Dam) is one of the many bodies of water that are present in the park. By means of physico-chemical and microbiological analysis, it was determined that the water of the Presa de los Patos cannot be considered potable. The $\mathrm{pH}$ range was between 5.5 - 5.9. The turbidity exceeded the values established in the standards (10.7 - 32.3 Nephelometric Turbidity Units (NTU's)). Chemical Oxygen Demand (COD) showed that large amounts of oxygen are needed to oxidize organic matter $(106-450 \mathrm{mg} / \mathrm{L})$. The amount of coliforms and fecal coliforms exceeds the values established by the standards used (total coliforms 98 - 956 Colony Forming Units (CFU's), fecal coliforms 78 - 807 CFU's). Five bacterial genera (Escherichia coli, Pseudomona, Klebsiella, Shigella and Salmonella) were isolated and identified. Most of the bacteria isolated were resistant to ampicillin (90\%), while $25 \%$ were resistant to ciprofloxacin. The water consumption of the Presa de los Patos is a great risk for the habitants and visitors of the park.
\end{abstract}

\section{Keywords}

Water, Physico-Chemical, Microbiological, Antimicrobial Resistance, Antibiotics

\section{Introduction}

Desierto de los Leones National Park is located in the central region of the Mexican Republic, southwest of the Mexico Basin. The park is located to the west of Mexico City, within the delegations Álvaro Obregón and Cuajimalpa de Morelos 
(Map 1). It has the category of National Park since 1917 to preserve and protect the natural resources in Mexico [1]. The park has a high biological, environmental and ecological value, and also has an important role for recreation of the habitants of Mexico City.

Water is the universal solvent capable of dissolving nearly all solutes, which is important to living and non-living things [2]. Water is a resource that has many uses, including recreation, transportation, and hydroelectric power, domestic, industrial, and commercial uses [3]. The water of rivers plays an important role in development of the countries [4]. Water is extraordinarily abundant on the planet as a whole, but fresh potable water is not always available at the right time or the right place for human or ecosystem use [5].

Water quality is defined as the set of physical, chemical and biological characters that must be satisfied in order to ensure that the water supplied is safe for the consumer [6]. Water pollution can cause adverse health effects for a representative number of people over predictable periods of time and is due to population growth, industrial development and urbanization [7]. In the recent past,

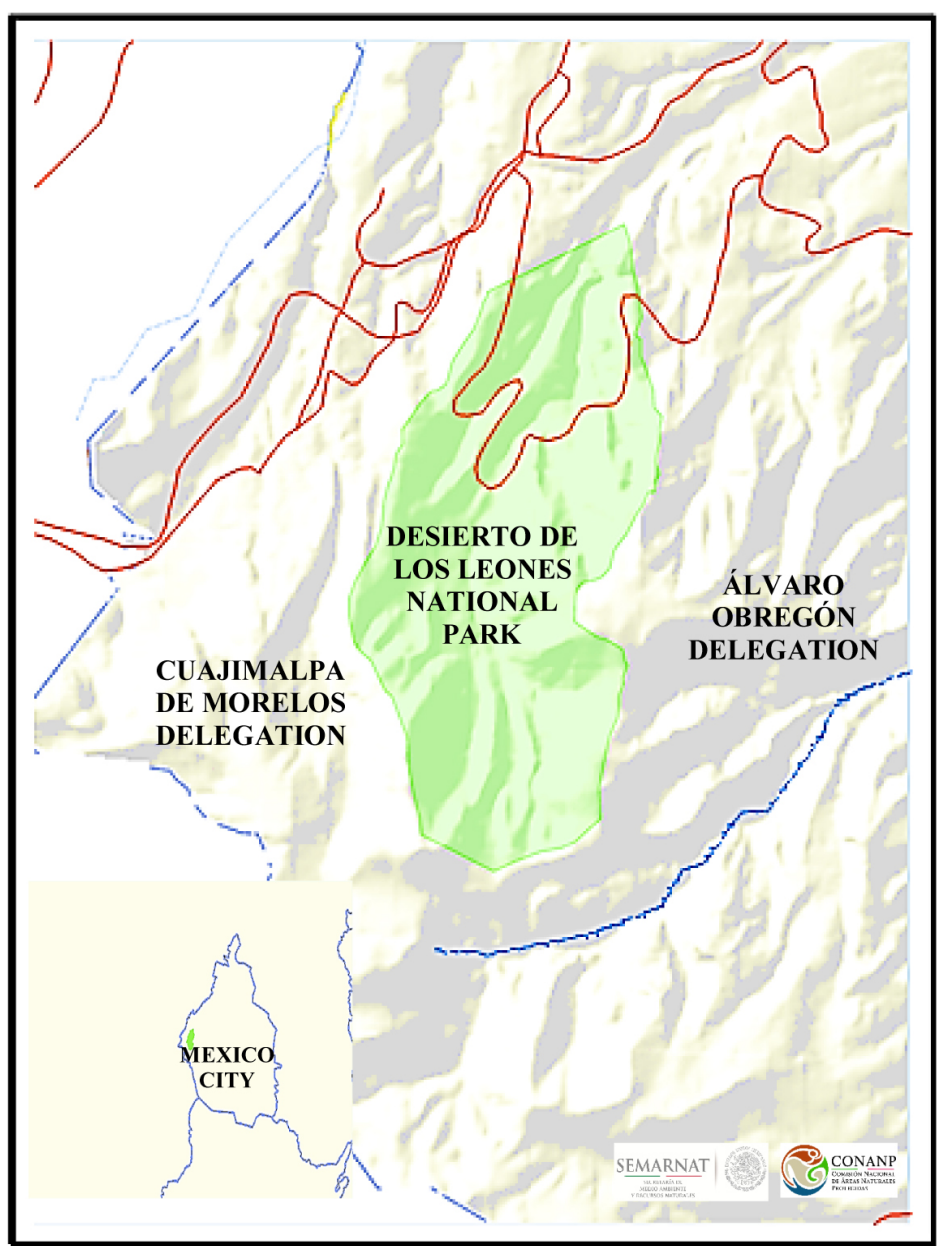

Map 1. Location of the desierto de los leones national park, Mexico City. The park is located to the west of Mexico City, within the delegations Álvaro Obregón and Cuajimalpa de Morelos. Source: CONANP (Comisión Nacional de Áreas Naturales Protegidas). 
expanding human population, industrialization, intensive agricultural practices and discharges of massive amount of wastewater into rivers have resulted in deterioration of water quality [8]. The improper management of water systems may cause serious problems in availability and quality of water since water quality and human are closely related [9]. For degradation of the quality of surface and groundwater, one of its origins is the direct discharge of contaminated water from domestic, industrial and agricultural sources into bodies of water [10].

Unfortunately, clean, pure and safe water only exists briefly in nature and is immediately polluted by prevailing environmental factors and human activities. Water from most sources is therefore unfit for immediate consumption without some sort of treatment [11]. The industrial pollutants associated with organic matter, inorganic dissolved solids and other unwanted chemicals cause serious problems in the water quality [12]. Water related diseases continue to be one of the major health problems globally due to consumption of contaminated water. The high prevalence of diarrhea among children and infants can be traced to the consumption of unsafe water [13]. The examination of microbiological river water quality according to technical standards is obligatory for use-related aspects such as for drinking water production, irrigation or recreation [14].

The principal risk to human health derives from fecal contamination [15]. Human fecal material is generally considered to be a greater risk to human health as it is more likely to contain human enteric pathogens. The most important aspect of water quality is its freedom from contamination with fecal matter [16]. The public health significance of water quality cannot be over emphasized. Many infectious diseases are transmitted by water through the fecaloral route [17]. Certain physical, chemical and microbiological standards are designed to ensure the safety of water for bathing and drinking before it can be described as potable [9]. This work shows the results obtained from the physico-chemical and microbiological analysis carried out on the water of the Presa de los Patos, as well as the antimicrobial susceptibility testing against two antibiotics commonly used in Mexico.

\section{Materials and Methods}

Physico-chemical and microbiological essays were performed based on the tests described in Official Mexican Norm 127 (NOM-127-SSA1-1994, Saludambiental, aguaparauso y consumohumano. Límitespermisibles de calidad y tratamientos a quedebesometerse el aguaparasupotabilización) [18], as well as the tests described in APHA-AWWA-WPCF (Standard Methods for Water and Waste Waters) [19].

\subsection{Study Area}

In the north of the Park a subhumid fresh climate prevails with an average temperature of $12^{\circ} \mathrm{C}$. On the other hand, in the western region of the park prevails a humid climate that oscillates between the $9^{\circ} \mathrm{C}-11^{\circ} \mathrm{C}$. In the east of the hills of the Desierto de los Leones there is a cold subhumid and humid climate, which 
causes the temperature to drop to $6^{\circ} \mathrm{C}$. Presa de los Patos is located in the Desierto de los Leones National Park, in Mexico City. It has the geographic coordinates: latitude $19^{\circ} 18^{\prime} 41.82^{\prime \prime} \mathrm{N}$, longitude $99^{\circ} 18^{\prime} 35.06^{\prime \prime} \mathrm{W}$ and approximate 2900 meters above sea level (Map 2).

\subsection{Sample Collection}

The water samples were collected during the winter. During the month of December of the year 2016, the Desierto de los Leones National Park realized Christmas events and different recreational activities, which caused a great amount of visitors to the Presa de los Patos. Water pollution was evident. For this reason it was decided to collect the samples during the month of January and carry out the analyzes already mentioned. They were collected from three different points along the place Presa de los Patos (the three sampling points were identified as high zone, middle zone and low zone). Two visits were made to the dam (with a week difference between each visit). A total of 18 samples were collected, each sample being approximately 3 liters.

\subsection{Physico-Chemical Analysis}

The physico-chemical parameters included the following tests: temperature (de-

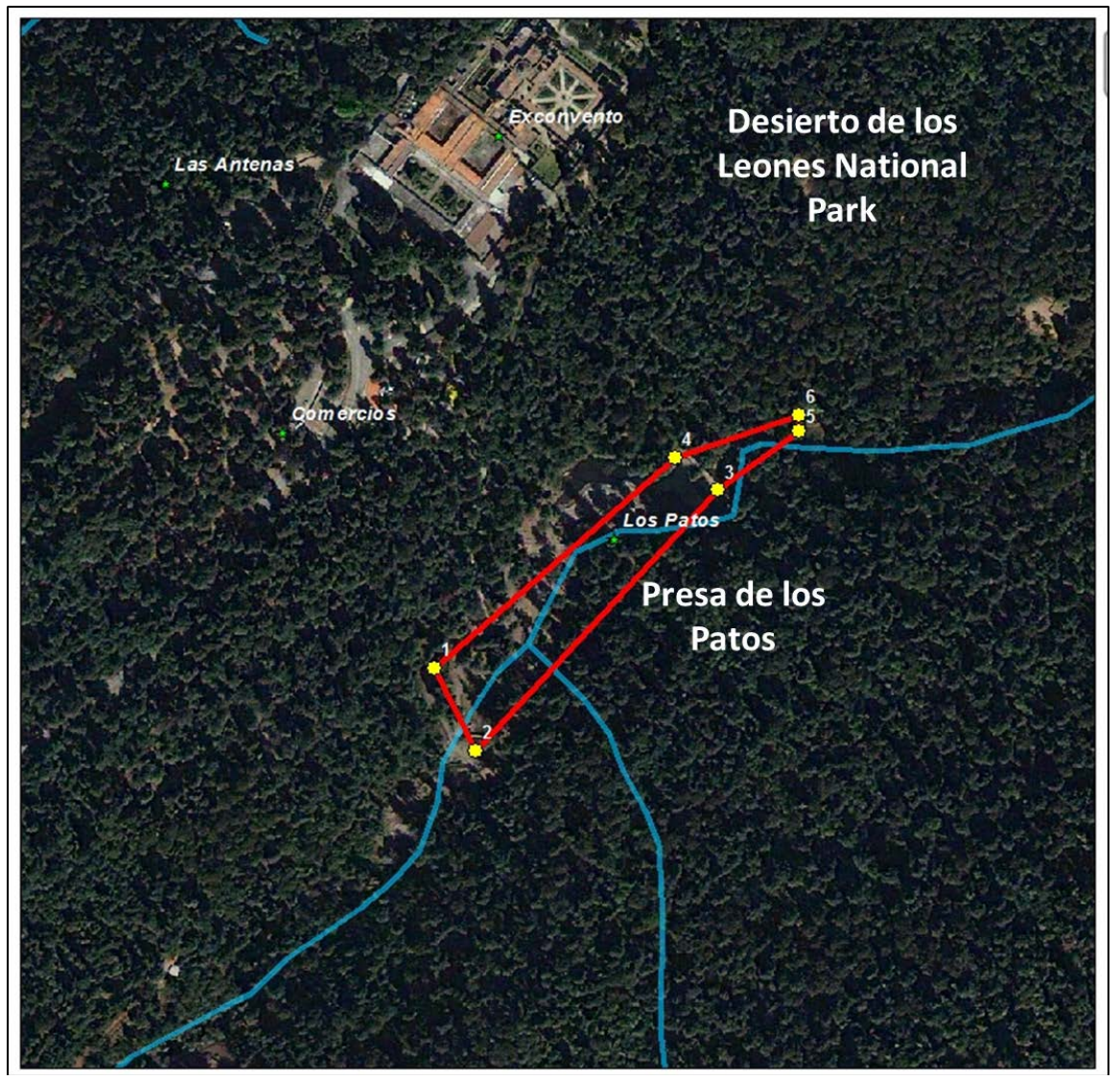

Map 2. Geographiccoordinates of Presa de los Patos. Presa de los Patos: latitude $19^{\circ} 18^{\prime} 41.82^{\prime \prime N}$, longitude $99^{\circ} 18^{\prime} 35.06^{\prime \prime W}$. Source: SEDEMA-DGCORENA (Secretaría de Medio Ambiente-Dirección General de la Comisión de Recursos Naturales). 
termined by using mercury in glass thermometer. The thermometer was rinsed with distilled water before and after each use, and the unit of measurement is centigrade degrees $\left.{ }^{\circ} \mathrm{C}\right), \mathrm{pH}(\mathrm{pH}$ was determined by using a $\mathrm{pH}$ meter calibrated by inserting the probe in $\mathrm{pH} 4.0,7.0$ and 10.0. The probe was dipped into each water sample and the $\mathrm{pH}$ measurement recorded), turbidity (this was measured by simple comparison of the interference of light rays passing through each water sample with that of standard samples. The spectrophotometer was used after it has been calibrated by 5 and 10 NTU standards and the unit of measurement was NTU), conductivity (this was carried out using a conductivity bridge meter (multi-parameter). The probe was dipped into each water sample and the conductivity measurements recorded in $\mu \mathrm{S} \cdot \mathrm{cm}^{-1}$ (microsiemen per centimeter), solids (a clean and dry evaporating dish of known weight was used. It was filled with $100 \mathrm{~cm}^{3}$ of each water sample and evaporated to dryness in an oven at $102^{\circ} \mathrm{C}-105^{\circ} \mathrm{C}$ to a constant weight), alkalinity (the $0.02 \mathrm{M} \mathrm{H}_{2} \mathrm{SO}_{4}$ was standardized with $0.02 \mathrm{M} \mathrm{NaOH}$ solution. About $100 \mathrm{~cm}^{3}$ of each water sample was taken and three drops of methyl orange indicator added which was titrated against standard $\mathrm{H}_{2} \mathrm{SO}_{4}$ ), chlorides (the $0.0282 \mathrm{M}$ silver nitrate was standardized with $0.0282 \mathrm{M}$ sodium chloride standard. About $100 \mathrm{~cm}^{3}$ of each water sample was taken into a conical flask and $1 \mathrm{~cm}^{3}$ of $5 \%$ potassium chromate indicator was added and titrated against standard silver nitrate solution), nitrates (the concentration of nitrates in a water sample was determined by measuring the absorbance in the ultraviolet range at $220 \mathrm{~nm}$ and comparing it with a calibration curve), chemical oxygen demand (COD) (the method is based on an energetic oxidation of organic matter and oxidizable inorganic matter found in water in a strongly acid medium with a titrated solution of potassium dichromate. The excess oxidizing agent is titrated with a titrated solution of ferrous ammoniumsulphate in the presence of a ferrous orthophenanthroline complex as an internal indicator), as described by NOM-127-SSA1-1994 and APHA.

\subsection{Microbiological Analysis}

The microbiological analysis included the following tests:

\subsubsection{Determination of Total Coliform Bacteria and Fecal Coliforms}

Fecal and total coliform counts were performed using the standard membrane filtration technique. The $100 \mathrm{ml}$ water sample was filtered using $0.45 \mathrm{~mm}$ pore size, $47 \mathrm{~mm}$ diameter filter membrane as described by NOM-127-SSA1-1994 and APHA.

\subsubsection{Isolation and Microbial Identification.}

Microbial isolation was performed from the water samples collected at the place Presa de los Patos. The culture media used were: MacConkey agar, eosin methylene blue agar, Salmonella-Shigella agar and brilliant green agar. Isolation was performed by streak plate technique. The cultures were incubated at $37^{\circ} \mathrm{C}$ overnight. After the incubation time, a new isolation was made in the same culture media and the morphology was analyzed to identify the bacterial genera. 


\subsection{Antimicrobial Susceptibility Testing}

The disk diffusion susceptibility method was done as previously described [20]. The antibiotics used were ampicillin and ciprofloxacin, both antibiotics are commonly used in Mexico. The concentration of antibiotic used for the disks was 10 and $15 \mu \mathrm{g}$.

\section{Results}

\subsection{Physico-Chemical Analysis}

The temperature determination was performed at the same time as the sample collection. The average temperature of the three sampling points is shown in Table 1.

The $\mathrm{pH}$ determination was performed at the same time as the sample collection. The average temperature of the three sampling points is shown in Table 2.

The middle zone and the low zone did not meet the allowable limits in the turbidity test. The conductivity test showed that the three sampling points are within the allowable limits, however, the low zone had a high conductivity compared to the other zones. The three zones analyzed comply with the parameters established for the solid test. The average of the results is shown in Table 3.

The values of alkalinity, chlorides and nitrates were within the permissible limits. In the chemical oxygen demand test, the middle zone and the low zone had values well above those established. The results are shown in Table 4.

Table 1. Average temperature at all three sampling points.

\begin{tabular}{lccc}
\hline & \multicolumn{3}{c}{ Sampling Points } \\
\cline { 2 - 4 } & High Zone & Middle Zone & Low Zone \\
\hline Temperature $\left({ }^{\circ} \mathrm{C}\right)$ & $5.7 \pm 0.63$ & $5.6 \pm 0.53$ & $4.4 \pm 0.68$ \\
\hline
\end{tabular}

The average temperature is similar in the three zones, however, in the low zone the temperature is around one degree lower than the other zones.

Table 2. Average $\mathrm{pH}$ at all three sampling points.

\begin{tabular}{cccc}
\hline & & Sampling Points & \\
\cline { 2 - 4 } & High Zone & Middle Zone & Low Zone \\
\hline $\mathrm{pH}$ & $7.3 \pm 0.3$ & $5.9 \pm 0.03$ & $5.5 \pm 0.07$ \\
\hline
\end{tabular}

Table 3. Physico-chemical analysis results.

\begin{tabular}{cccc}
\hline & \multicolumn{3}{c}{ Sampling Points } \\
\cline { 2 - 4 } & High Zone & Middle Zone & Low Zone \\
\hline Turbidity $(\mathrm{NTU})$ & 1.1 & 10.7 & 32.3 \\
Conductivity $(\mu \mathrm{S} / \mathrm{cm})$ & 20.6 & 70.2 & 421.6 \\
Solids $(\mathrm{mg} / \mathrm{L})$ & 53 & 142 & 250 \\
\hline
\end{tabular}

Allowable Limits: Turbidity (5 NTU), Conductivity (1200 $\mu \mathrm{S} / \mathrm{cm})$, Solids (500 mg/L). 
Table 4. Physico-chemical analysis results.

\begin{tabular}{cccc}
\hline & \multicolumn{3}{c}{ Sampling Points } \\
\cline { 2 - 4 } & High Zone & Middle Zone & Low Zone \\
\hline Alkalinity $(\mathrm{mg} / \mathrm{L})$ & 48 & 100 & 197 \\
Chlorides $(\mathrm{mg} / \mathrm{L})$ & 10 & 78 & 193 \\
Nitrates $(\mathrm{mg} / \mathrm{L})$ & 1 & 1.3 & 6 \\
Chemical Oxygen & 1.1 & 106 & 450 \\
Demand (mg/L) & & & \\
\hline
\end{tabular}

Allowable limits: alkalinity $(300 \mathrm{mg} / \mathrm{L})$, chlorides $(250 \mathrm{mg} / \mathrm{L})$, nitrates $(10 \mathrm{mg} / \mathrm{L})$, chemical oxygen demand $(2 \mathrm{mg} / \mathrm{L})$.

\subsection{Microbiological Analysis}

\subsubsection{Determination of Total Coliforms Bacteria and Fecal Coliforms}

The results of the total and fecal coliform counts are shown in Table 5. The middle and low zones showed a high number of colony forming units.

\subsubsection{Isolation and Microbial Identification}

The culture media that were inoculated with the samples of water from the middle and low zones presented growth (Figure 1). Twelve different types of colony were isolated (Figure 2). Morphological analysis of the isolated colonies was performed, and five bacterial genera were identified (Table 6).

\subsection{Antimicrobial Susceptibility Testing}

Over $75 \%$ of the strains isolated showed inhibition against ciprofloxacin, while 90\% showed resistance to ampicillin (Figure 3 and Figure 4). The results of the antimicrobial susceptibility testing are shown in Table 7.

\section{Discussion}

Water is an important natural resource on earth. It is necessary for all living organisms, ecological system, human health, food production and economic development. Water can be obtained from a number of sources, among which are streams, lakes, rivers, ponds, rain, springs [21]. Water is very essential to the survival of all organisms. The human body is composed of approximately $70 \%$ water by mass [22]. The water can be considered as the most important natural resource, because it is vital to life [23]. Fresh water has become a fundamental topic of debate around the world. There is no human activity with which water has no relation, and the problems around it are as diverse as its actors. In particular, Mexico suffers from major water problems of various kinds: infrastructure, conservation, financing, pollution, distribution, equity in access, management, as well as high vulnerability to global climate change [24].

Mexico City is one of the most populated cities in the world. The Desierto de los Leones is a natural space that has propitiated the maintenance of the ecosystems that compose it, allowing the production of environmental goods and services on which the population of Mexico City depends directly. This area favors 
Table 5. Total coliform bacteria and fecal coliforms.

\begin{tabular}{cccc}
\hline & \multicolumn{3}{c}{ Sampling Points } \\
\cline { 2 - 4 } & High Zone & Middle Zone & Low Zone \\
\hline Total Coliforms $(\mathrm{CFU} / 100 \mathrm{ml})$ & 2 & 98 & 956 \\
Fecal Coliforms $(\mathrm{CFU} / 100 \mathrm{ml})$ & 0 & 78 & 807 \\
\hline
\end{tabular}

Allowable limits: total coliform (0 CFU/100 ml), fecal coliforms (0 CFU/100 ml).

Table 6. Bacterial genera identified.

\begin{tabular}{ccc}
\hline & \multicolumn{2}{c}{ Sampling Points } \\
\cline { 2 - 3 } & High Zone & Liddle Zone \\
Bacterial Ge- & \multicolumn{2}{c}{ Escherichiacoli } \\
nera & - & Klebsiella \\
& & Salmonella \\
& Shigella \\
& \multicolumn{2}{c}{ Pseudomona } \\
\hline
\end{tabular}

Five bacterial genera were identified.

Table 7. Antimicrobial susceptibility testing.

\begin{tabular}{|c|c|c|c|}
\hline Plate Number & Strains Isolated & Ampicillin & Ciprofloxacin \\
\hline 1 & Shigella & - & ++ \\
\hline 2 & Shigella & +++ & +++ \\
\hline 3 & Pseudomona & + & ++ \\
\hline 4 & Pseudomona & + & +++ \\
\hline 5 & Salmonella & - & - \\
\hline 6 & Klebsiella & - & +++ \\
\hline 7 & Klebsiella & + & +++ \\
\hline 8 & Klebsiella & - & ++ \\
\hline 9 & Escherichia coli & - & + \\
\hline 10 & Escherichia coli & - & + \\
\hline 11 & Escherichia coli & - & ++ \\
\hline 12 & Escherichia coli & - & ++ \\
\hline
\end{tabular}

Without inhibition $(-)$, low inhibition $(+)$, middle inhibition $(++)$, high inhibition $(+++)$.

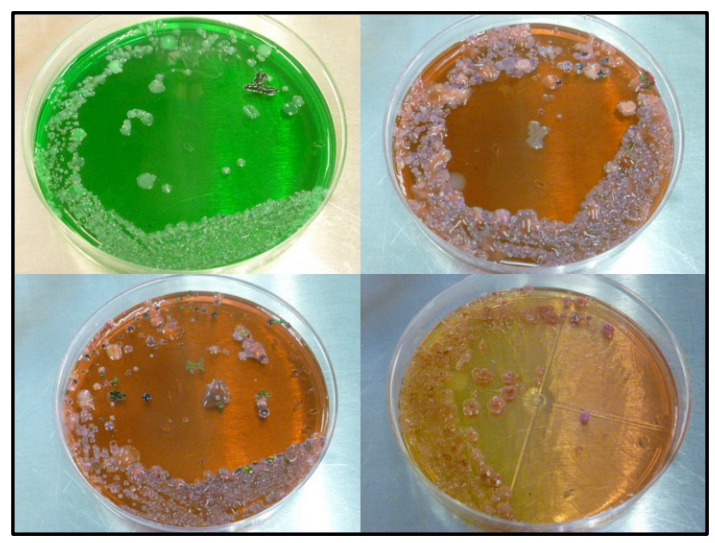

Figure 1. Colony growth in the different culture media. Colony growth was observed in the different culture media used. 


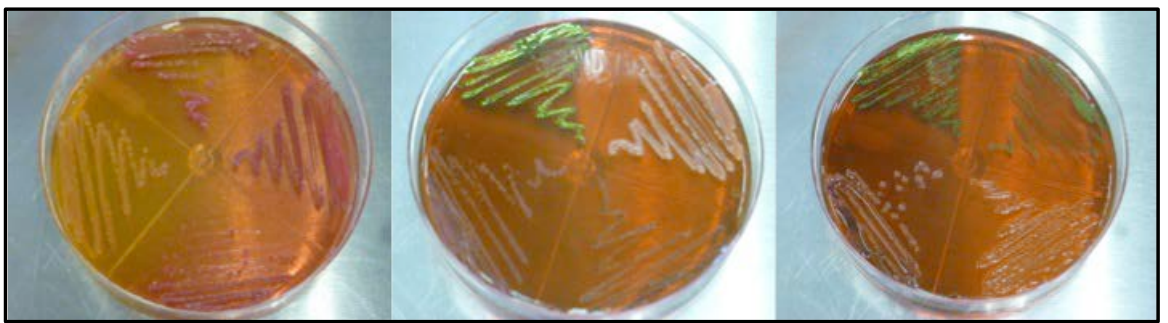

Figure 2. Different types of isolated colony. Twelve different types of colonies were isolated.

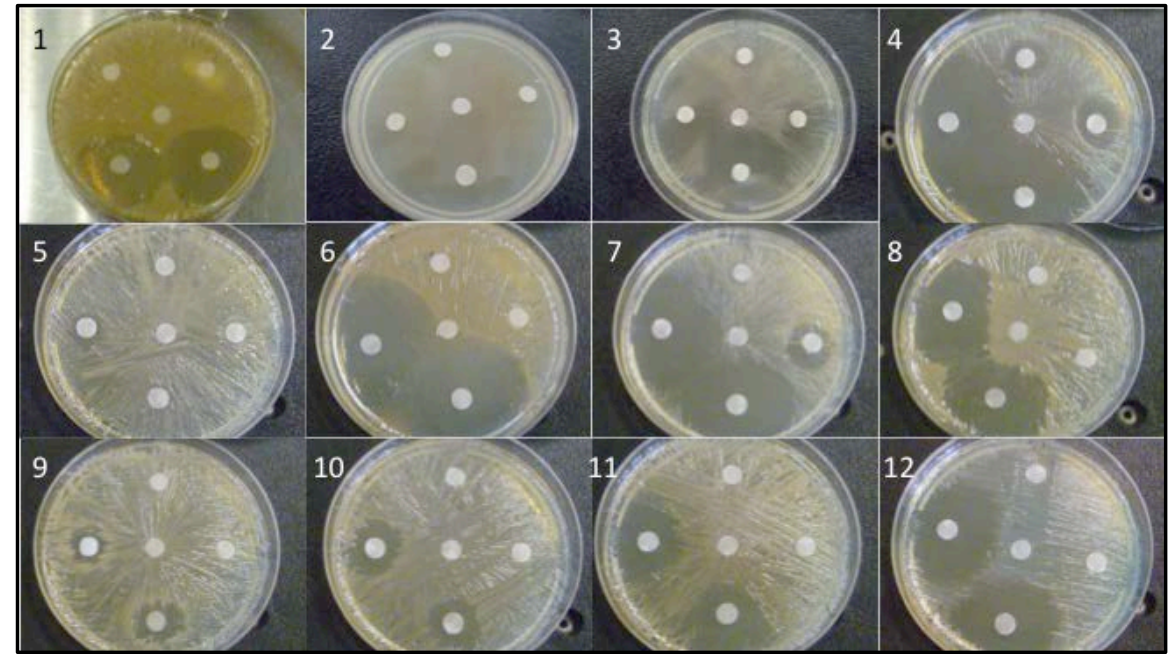

Figure 3. Antimicrobial susceptibility testing. Ampicillin: 10 and $15 \mu \mathrm{g}$. Central Disk: Without Antibiotic. Ciprofloxacin: 10 and $15 \mu \mathrm{g}$.

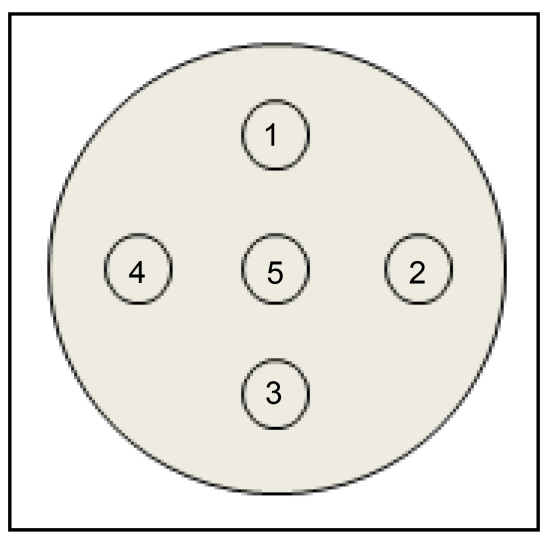

Figure 4. Disk diffusion test. 1) Ampicillin10 $\mu \mathrm{g}, 2)$ Ampicillin $15 \mu \mathrm{g}, 3) \mathrm{Ci}$ profloxacin $10 \mu \mathrm{g}$, 4) Ciprofloxacin $15 \mu \mathrm{g}$ and 5) Negative control.

retention of moisture and recharge of the aquifer, prevents erosion, contributes to improving air quality, as well as to sustaining and improving populations of wild flora and fauna. In addition to its high biological value, the Desierto de los Leones plays an important role in the provision of recreational and recreational opportunities for the habitants of Mexico City [1]. Presa de los Patos is a place 
where families from Mexico City and visitors from other places can have recreational activities, practice sports, cook, celebrate special dates, etc. In the place we can find ducks that live permanently in the dam, for them, contact with humans is routine. There are rudimentary grills that visitors occupy to prepare their food, as well as around there are places where they can consume already prepared foods. However, most of these establishments discharge their wastewater directly to the dam. The drainage pipes are exposed on the surface, this can cause the rupture of some of them and that the discharge of waste water is distributed to several points of the dam. Visitors also contribute to the pollution of the place, because we find EPS plates (EPS: expanded polystyrene), plastic and EPS glasses, plastic spoons, bottles and cans of soda, paper napkins and food remains floating on the water. All of the above contributes greatly to the contamination of the dam's water. The physico-chemical analysis carried out on the dam's water included the following tests: temperature, $\mathrm{pH}$, turbidity, conductivity, solids, alkalinity, chlorides, nitrates, chemical oxygen demand (COD) [18] [19]. The evaluation of physico-chemical analysis is of great importance in determining the factors that directly influence water quality. This type of analysis provides useful and specific data on the decomposition and intensity of contaminated wastewater or streams, for treatment, evaluation and prevention purposes [25]. As described by Tabbut (1999), the physico-chemical parameters that were determined at the site of the sample collection were the following: temperature, $\mathrm{pH}$ and conductivity [26].

The temperature value is determined by the amount of solar energy absorbed by the mass of water and by the soil and air surrounding it, as well as by evaporation on its surface. High temperature values occur because of increased solar heating, but can also be caused by human activities that use water. Temperature plays a very important role in the biological balance and in the solubility of oxygen and mineral salts. The measurement of temperature in environmental samples must be a work done in situ, and therefore does not apply the procedures of storage and preservation. The best method for reading this parameter is to directly introduce the measuring equipment (thermometer or probe) into the water body [27]. The temperature of the three sampling points was in the range of $4.45^{\circ} \mathrm{C}$ to $5.71^{\circ} \mathrm{C}$, water samples were collected during the month of January. The temperature values are lower than those reported by Taiwo et al. (2014) [2] and Mladinic et al. (1987) [28] in other rivers and lakes, this can be explained by the characteristics of this dam located at an altitude of approximately 2900 meters above sea level and the area has a temperature of 9 to $11^{\circ} \mathrm{C}$.

$\mathrm{pH}$ is a measure of the acidity or basic (alkaline) nature of a solution [29]. The middle zone and the low zone showed acid $\mathrm{pH}$ values (5.9 and 5.5, respectively). Low $\mathrm{pH}$ 's also increase the release of metals, some toxic, from soils and sediments [29]. According to the NOM-127-SSA1-1994, the $\mathrm{pH}$ of the drinking water should be between 6.5 - 8.5, the water of the dam does not meet the established. Our data is different from those reported by Romeu et al. (2012) [30], Torres (2008) [31], Geetha et al. (2014) [32], Fatombi et al. (2012) [33] that came 
from another water bodies.

Turbidity in water is caused by suspending organic or inorganic material [25]. Solid particles suspended in water absorb or reflect light and cause the water to appear "cloudy". These particles are suspended inorganic minerals or organic matter picked up over or under the ground [29]. According to the NOM-127SSA1-1994, the turbidity limit of drinking water must be 5 NTU. The middle zone and the low zone did not comply with the turbidity limits, both presented higher values than those established (10.7 and 32.3 NTU). The major problem with turbidity is aesthetic, but in some cases suspended matter can carry pathogens with it [29]. Our data are similar to those reported by Taiwo et al. (2014) [2], Karikari et al. (2006) [5], Olorode et al. (2015) [9], Shittu et al. (2008) [17].

Conductivity is defined as the ability of a substance to carry electrons (electric current). In water, this capacity is influenced by the amount of dissolved salts and the temperature. This means that at higher salt content, higher conductivity. In this way, this property can be used to measure the content of salts in a sample of water (25). According to the NOM-127-SSA1-1994, the drinking water conductivity limit must be $1200 \mu \mathrm{S} / \mathrm{cm}$. All three sampling points were below the limit. Our data are similar to those reported by Taiwo et al. (2014) [2], Karikari et al. (2006) [5], Olorode et al. (2015) [9], Vázquez et al. [10], Ladokun (2015) [13], Shittu et al. (2008) [17]. The term "solids" refers to solid matter suspended or dissolved in water or waste. The solids can adversely affect water quality in several ways: high solids waters are less pleasing to human taste and may induce an unfavorable physiological reaction in the consumer. Highly mineralized waters are also unsuitable for many industrial applications, for these reasons, the limit of $500 \mathrm{mg} / \mathrm{L}$ of solids is desirable for drinking water. Highly mineralized waters are useless for many industrial applications; and those having high dissolved solids content may be aesthetically unsatisfactory for purposes such as bathing [18] [27]. All three sampling points were below the limit. Our data are similar to those reported by Taiwo et al. (2014) [2], Karikari et al. (2006) [5], Olorode et al. (2015) [9], Vázquez et al. [10], Shittu et al. (2008) [17].

Alkalinity is the ability to react with the hydrogen ions of water, being mainly caused by the carbonate $\left(\mathrm{CO}_{3}^{-}\right)$and bicarbonate $\left(\mathrm{HCO}_{3}^{-}\right)$ions, although it is also influenced by the content in others such as borates, phosphates, silicates and oxydriles [34]. The alkalinity is influenced by the $\mathrm{pH}$, the general composition of the water, the temperature and the ionic strength [35]. According to the NOM127-SSA1-1994, the alkalinity limit for drinking water is $300 \mathrm{mg} / \mathrm{L}$. The three zones evaluated showed values that did not exceed the allowed limits. Our data are above those reported by Taiwo et al. (2014) [2], Karikari et al. (2006) [5], Olorode et al. (2015) [9], Vázquez et al. [10], Ladokun et al. (2015) [13]. Excessive chloride concentration increases rates of corrosion of metals. Chloride is one of the major anion in water, and it is generally associated with sodium. High level of chloride ions may result in an objectionably salty taste [21]. According to NOM-127-SSA1-1994, the presence of chlorides in drinking water must be 250 $\mathrm{mg} / \mathrm{L}$ as a limit. All evaluated areas showed acceptable values. Our data vary with 
those reported by Taiwo et al. (2014) [2], Olorode et al. (2015) [9], Shittu et al. (2008) [17], Choudhury et al. (2016) [21], Fatombi et al. (2012) [33] that came from different bodies of water.

The Nitrates $\left(\mathrm{NO}_{3}^{-}\right)$are very soluble salts, derived from nitrogen, which can be found in food and drinking water. They derive mainly from the use of nitrogen fertilizers, animal excreta, discharges from sanitary and industrial waste, and from the use as food additives (preserved fish and meat). If a water resource receives domestic wastewater discharges, nitrogen will be present as organic ammoniacal nitrogen, which, in contact with dissolved oxygen, will be transformed by oxidation into nitrites and nitrates. This nitrification process depends on the temperature, the dissolved oxygen content and the $\mathrm{pH}$ of the water [35]. According to NOM-127-SSA1-1994, the presence of nitrates in drinking water must be $10 \mathrm{mg} / \mathrm{L}$ as a limit. All evaluated areas showed acceptable values. Our data vary with those reported by Taiwo et al. (2014) [2], Karikari et al. (2006) [5], Olorode et al. (2015) [9], Choudhury et al. (2016) [21], Fatombi et al. (2012) [33].

COD is one of the most effective parameters in the control of water quality; constitutes the amount of chemical oxidant that is needed to be able to oxidize the materials contained in the water. Quantifies the amount of total organic matter susceptible to chemical oxidation (biodegradable and non-biodegradable) in a liquid sample and is used to establish the level of contamination [36]. According to the NOM-127-SSA1-1994, the permissible limit of the chemical oxygen demand test is $2 \mathrm{mg} / \mathrm{L}$. The middle zone and the low zone presented values much greater than the established by the norm. Our data vary with those reported by Rajiv et al. (2012) [3], Sood et al. (2008) [8], Vázquez et al. [10], Choudhury et al. (2016) [21], Abdo et al. (2015) [26].

The middle zone and the low zone did not meet with the limits established for the tests of $\mathrm{pH}$, turbidity and chemical oxygen demand. $\mathrm{pH}$ is acidic, which can cause harm to the health of consumers. The water turbidity was evident, and the values obtained far exceed those established by the standards. The values of chemical oxygen demand showed that large amounts of oxygen are needed to oxidize organic matter. The rest of the physico-chemical tests showed values that do not exceed the established limits, however, the majority of the obtained values is very close to the allowed limits. Water is examined microbiologically to determine its sanitary quality and its suitability for general use. The aim being that it will be acceptable for internal consumption and other uses in contact with man. Water may contain poisonous chemical substances, pathogenic organisms (infectious and parasitic agents), industrial or other wastes or sewage and is referred to as being contaminated or polluted. Most of the infections in developing countries can be attributed to lack of safe drinking water (like cholera, typhoid, Hepatitis, Poliomyelitis etc.) [36]. The NOM-127-SSA1-1994 establishes that for drinking water, there should be no presence of coliforms and fecal coliforms. The middle zone and the low zone presented values much higher than those established. In both tests, the number of colony forming units ranged from 70 - 
1000 CFU's. Our data are congruent with those reported by Ohanu et al. (2012) [36], Niewolak et al. (1999) [37], Johnson et al. (2016) [38], Hounsinou et al. (2015) [39], Antony et al. (2012) [40]. The fecal contamination of water is a factor of sanitary importance because the feces contain a great variety of microorganisms, being able to contain even entero-pathogenic microorganisms like bacteria of the sort Salmonella, Shigella and Vibrio; Protozoa such as Entamoebahistolytica; Viruses such as enterovirus or hepatitis A [6]. The presence of E. coli in water is used as an indicator to monitor the possible presence of other harmful microbes such as Eryptosporidium giardia, Shigella and noro virus [2]. In this study, five bacterial genera (Escherichia coli, Klebsiella, Pseudomona, Salmonella and Shigella) were identified. Our results are consistent with those reported by Olorode et al. (2015) [9], Omezuruike et al. (2008) [11], Shittu et al. (2008) [17], Choudhury et al. (2016) [21], Lawal et al. (2011) [22], Fatombi et al. (2012) [33], Antony et al. (2012) [40]. Antimicrobial agents are classified by their specific modes of action against bacterial cells. These agents may interfere with cell wall synthesis, inhibit protein synthesis, interfere with nucleic acid synthesis or inhibit a metabolic pathway. The modes of action of antimicrobial agents against gram-positive and gram-negative bacteria are very similar [41]. Ciprofloxacin and ampicillin are two antibiotics commonly used in Mexico. For this reason they were used in the antimicrobial resistance test. Of the twelve isolates that were obtained, $90 \%$ were resistant to ampicillin, while $25 \%$ were resistant to ciprofloxacin. Our data are congruent with those obtained byMulla et al. (2016) [42], Bosco et al. (2012) [43], Krishnan et al. (2012) [44], Falodun et al. (2016) [45], Shatalov et al. (2015) [46]. There are a number of ways by which microorganisms are resistant to antimicrobial agents. These include: 1) the bacteria produce enzymes that either destroy the antimicrobial agent before it reaches its target or modify the drug so that it no longer is recognized by the target; 2) the cell wall becomes impermeable to the antimicrobial agent; 3 ) the target site is altered by mutation so that it no longer binds the antimicrobial agent; 4) the bacteria possess an efflux pump that expels the antimicrobial agent from the cell before it can reach its target; and 5) specific metabolic pathways in the bacteria are genetically altered so that the antimicrobial agent cannot exert an effect [41].

\section{Conclusion}

The physico-chemical and microbiological analysis carried out at the Presa de los Patos in the Desierto de los Leones National Park showed that the water cannot be considered potable. Water does not meet physico-chemical and microbiological parameters, and they get worse in the low zone. Its consumption is a risk to the health of the residents and visitors. The microbiological analysis showed that the water is contaminated by bacteria that are highly dangerous for the human. In addition to these data, the major concern is in the resistance of bacteria to the antibiotics used. The diseases caused by the microorganisms identified in this study can cause serious damage to the population, especially the child population. 
The Desierto de los Leones National Park has a large number of bodies of water, therefore, it is necessary to perform the same analysis in future work that can indicate the degree of water contamination. It will also be necessary to identify the species of the genera isolated in this study. The results of this study showed the degree of contamination of the Presa de los Patos during the month of January of the year 2017. Physico-chemical and microbiological analyses are necessary in each of the months to monitor the degree of contamination of the water in the different seasons of the year.

\section{Acknowledgements}

This work was carried out thanks to the collaboration of the "Consejo Asesorpara el Rescatedel Parque Nacional Desierto de los Leones". Thanks to the staff and facilities of the Universidad Autónoma Metropolitana-Cuajimalpa. Thanks to the Vinculación Department of UAM-C.

\section{References}

[1] Gobierno del Distrito Federal (2006) Programa de Conservación y Manejo Parque Nacional Desierto de los Leones.1a Edición. Comisión Nacional de Áreas Naturales Protegidas.

[2] Taiwo, A.G., Adewunmi, A.R., Ajayi, J.O., Oseni, O.A. and Lanre-lyanda, Y.A. (2014) Physico-Chemical and Microbial Analysis of the Impact of Abatoir Effluents on Ogun River Course. International Journal of Chem Tech Research, 6, 3083-3090.

[3] Rajiv, P., Hasna, A.S., Kamaraj, M., Rajeshwari, S. and Sankar, A. (2012) Physico Chemical and Microbial Analysis of Different River Waters in Western Tamil Nadu, India. Research Journal of Environment Sciences, 1, 2-6.

[4] Abd Al-Kareem, A.F., Al-Arajy, K.H. and Jassim, K.A. (2015) Microbiological Analysis on Tigris River Water in the Selected Sites in Baghdad Province, Iraq. Journal Environment and Earth Science, 5, 60-65.

[5] Karikari, A.Y. and Ansa-Asare, O.D. (2006) Physico-Chemical and Microbial Water Quality Assessment of the Densu River of Ghana. West African Journal of Applied Ecology, 10, 87-100.

[6] Cázares-Méndez, I.G. and Alcántara-Araujo, J.J. (2014) Análisis Microbiológico de la Calidad del Agua de Ciudad Nezahualcóyotl, Acorde a la Norma Oficial Mexicana NOM-127-SSA1-1994. Congreso Iberoaméricano de Ciencia, Tecnología, Innovación y Educación, 1-30.

[7] Martínez-Romero, A., Fonseca-Gómez, K., Ortega-Sánchez, J.L. and Garcia-Lujan, C. (2009) Monitoreo de la Calidad Microbiológica del Agua en la Cuenca Hidrológica del Río Nazas, México. Revista Química Viva, 1, 35-47.

[8] Sood, A., Deep-Singh, K., Pandey, P. and Sharma, S. (2008) Assessment of Bacterial Indicators and Physicochemical Parameters to Investigate Pollution Status of Gangetic River System of Uttarakhand (India). Ecological Indicators, 8, 709-717.

[9] Olorode, O.A., Bamigbola, E.A. and Ogba, O.M. (2015) Comparative Studies of Some River Waters in Port Harcourt Based on Their Physico-Chemical and Microbiological Analysis, Niger Delta Region of Nigeria. International Journal of Basic and Applied Science, 3, 29-37.

[10] Vázquez, J. and Domínguez, E. Calidad de Agua en el Valle de México. http://www.bvsde.paho.org/bvsaidis/mexico13/144.pdf 
[11] Omezuruike, O.I., Damilola, A.O., Adeola, O.T., Fajobi, E.A. and Shittu, O.B. (2008) Microbiological and Physicochemical Analysis of Different Water Samples Used For Domestic Purposes in Abeokuta and Ojota, Lagos State, Nigeria. African Journal of Biotechnology, 7, 617-621.

[12] Radha, R., Dharmaraj, K. and Ranjitha, B.D. (2007) A Comparative Study on the Physicochemical and Bacterial Analysis of Drinking, Borewell and Sewage Water in the Three Different Places of Sivakasi. Journal Environmental Biology, 28, 105-108.

[13] Ladokun, O.A. and Oni, S.O. (2015) Physico-Chemical and Microbiological Analysis of Potable Water in Jericho and Molete Areas of Ibadan Metropolis. Advances in Biological Chemistry, 5, 197-202. https://doi.org/10.4236/abc.2015.54016

[14] Kavka, G.G., Kasimir, G.D. and Farnleitner, A.H. (2006) Microbiological Water Quality of the River Danube (Km 2581-Km 15): Longitudinal Variation of Pollution as Determined by Standar Parameters. Proceedings of the 36th International Conference of IAD, Austrian Committee Danube Research/IAD, Vienna, 415-421.

[15] Water Sampling and Analysis. www.who.int/water_sanitation_health/dwq/2edvol3d.pdf

[16] Baghel, V.S., Gopal, K., Dwivedi, S. and Tripathi, R.D. (2005) Bacterial Indicators of Faecal Contamination of the Gangetic River System Right at Its Source. Ecological Indicators, 5, 49-56.

[17] Shittu, O.B., Olaitan, J.O. and Amusa, T.S. (2008) Physico-Chemical and Bacteriological Analyses of Water Used for Drinking and Swimming Purposes in Abeokuta, Nigeria. African Journal of Biomedical Research, 11, 285-290.

[18] Norma Oficial Mexicana NOM-127-SSA1-1994, Salud Ambiental, Agua para Uso y Consumo Humano. Límites Permisibles de Calidad y Tratamientos a que Debe Someterse el Agua para su Potabilización.

[19] Standard Methods for the Examination of Water and Wastewater.

[20] Jorgensen, J.H. and Ferraro, M.J. (2009) Antimicrobial Susceptibility Testing: A Review of General Principles and Contemporary Practices. Clinical Infectious Diseases, 49, 1749-1755. https://doi.org/10.1086/647952

[21] Choudhury, S., Keot, A., Das, H., Das, M., Baishya, C., Sarma, A. and Deka, P. (2016) Preliminary Physicochemical and Microbiological Analysis of Bahini River Water of Guwahati, Assam, India. International Journal of Current Microbiology and Applied Sciences, 2, 684-692.

[22] Lawal, R.A. and Lohdip, Y.N. (2011) Physicochemical and Microbial Analysis of Water from Mimyak River in Kanke LGA of Plateau State, Nigeria. African Journal of Natural Sciences, 14, 5-7.

[23] Mecanismos e Instrumentos para el Monitoreo de la Calidad del Agua. http://lasa.ciga.unam.mx/monitoreo/images/biblioteca/29\%20mecanismos_monitor eo_calidad_agua.pdf

[24] Fondo para la Comunicación y la Educación Ambiental A.C., Centro Mexicano de Derecho Ambiental A.C. and Presencia Ciudadana Mexicana A.C. (2006) El Agua en México: Lo que Todas y Todos Debemos Saber. $1^{\text {a }}$ Edición. México.

[25] Analisis Fisicoquímico en la Cuenca del Río San Juan. http://cdigital.dgb.uanl.mx/te/1020123766/1020123766_02.pdf

[26] Abdo, M.H., El-Sharkawy, M.H., El-Kordy, M.H. and Mostafa, M.E. (2015) Assessment and Chemical Treatment of Heavy Metals-Bearing Industrial Waste Water Discharged into the River Nile: Case Study. International Journal of Environmental Science and Engineering, 6, 105-112.

[27] Instituto de Investigaciones Marinas y Costeras José Benito Vives de Andréis 
(INVEMAR) (2003) Manual de Técnicas Analíticas para la Determinación de Parámetros Fisicoquímicos y Contaminantes Marinos (Aguas, Sedimentos y Organismos).

[28] Mladinic, P.A., Hrepic, N.V. and Quintana, E.H. (1987) Caracterización Física y Química de las Aguas de los Lagos Chungará y Cotacotani. Archivos de Biología y Medicina Experimentales, 20, 89-94.

[29] Asamoah-Boateng, E.K. (2009) Physico-Chemical and Microbiological Quality of Surface Waters within the Newmont Ghana Gold Mining Concession Areas. Master of Sciences Thesis, Kwame Nkrumah University of Science and Technology, Ghana.

[30] Romeu-Álvarez, B., Larrea-Murrell, J., Lugo-Moya, D., Rojas-Hernández, N. and Heydrich-Pérez, M. (2012) Calidad Microbiológica de las Aguas del Río Luyanó, La Habana, Cuba. Revista CENIC Ciencias Biológicas, 43, 1-10.

[31] Torres-Flores, J.A. (2008) Análisis de la Calidad Fisicoquímica y Microbiológica del Agua del Río Motagua en Diez Puntos de Muestreo Ubicados en su Cauce Principal. Proyecto de Investigación. Universidad de San Carlos, Guatemala.

[32] Geetha, S., Jagadeesh-Chandrababu, P., Nageswarrao, L. and Muralimohan, M. (2014) Physico-Chemical and Microbial Analysis of Water Samples in Anakapalli Municipal Corporation (India). Indian Journal of Current Science, 10, 108-115.

[33] Fatombi, K.J., Ahoyo, T.A., Nonfodji, O. and Aminou, T. (2012) Physico-Chemical and Bacterial Characteristics of Groundwater and Surface Water Quality in the Lagbe Town: Treatment Essays with Moringa oleifera Seeds. Journal of Water Resource and Protection, 4, 1001-1008. https://doi.org/10.4236/jwarp.2012.412116

[34] Aznar-Jiménez, A. (2000) Determinación de los Parámetros Fisico-Químicos de Calidad de las Aguas. Gestión Ambiental, 2, 12-19.

[35] Barrenechea-Martel, A. Aspectos Fisico-Químicos de la Calidad del Agua. http://www.ingenieroambiental.com/4014/uno.pdf

[36] Ohanu, M.E., Udoh, I.P. and Eleazar, C.I. (2012) Microbiological Analysis of Sachet and Tap Water in Enugu State of Nigeria. Advances in Microbiology, 2, 547-551. https://doi.org/10.4236/aim.2012.24070

[37] Niewolak, S. (2000) Bacteriological Monitoring of River Water Quality in the North Area of Wigry National Park. Polish Journal of Environmental Studies, 9, 291-299.

[38] Johnson, R.C., Boni, G., Amoukpo, H., Barogui, Y., Diez, G., Agossadou, D., Sopoh, G.E. and Boko, M. (2016) Microbiological Quality Assessment Water in Lalo Commune, Benin (West Africa). Journal of Water Resource and Protection, 8, 816-822. https://doi.org/10.4236/jwarp.2016.88066

[39] Hounsinou, P.S., Mama, D., Agassounon, M., Boukari, M. and Sohounhloue, D. (2015) Microbiological Pollution Indication as Tracer for the Pollution of Well Water: The Example of the District of Abomey-Calavi (Benin). Journal of Environmental Protection, 6, 290-298. https://doi.org/10.4236/jep.2015.64029

[40] Antony, R.M. and Renuga, F.B. (2012) Microbiological Analysis of Drinking Water Quality of Ananthanar Channel of Kanyaakumari District, Tamil Nadu, India. Ambiente e Agua-An Interdisciplinary Journal of Applied Science, 7, 42-48. https://doi.org/10.4136/ambi-agua.881

[41] Coyle, M.B., et al. (2005) Manual of Antimicrobial Susceptibility Testing. American Society for Microbiology.

[42] Mulla, S., Kumar, A. and Rajdev, S. (2016) Comparison of MIC with MBEC Assay for in Vitro Antimicrobial Susceptibility Testing in Biofilm Forming Clinical Bacterial Isolates. Advances in Microbiology, 6, 73-78.

https://doi.org/10.4236/aim.2016.62007 
[43] Bosco, K.J., Haddu-Mulindwa, D.H. and Asiimwe, B.B. (2012) Antimicrobial Drug Resistance and Plasmid Profiles of Salmonella Isolates From Humans and Foods of Animal Origin in Uganda. Advances in Infectious Diseases, 2, 151-155. https://doi.org/10.4236/aid.2012.24025

[44] Krishnan, S., Balasubramanian, D., Raju, B.A. and Lakshmi, B.S. (2012) Use of a Naturally Occurring Codon Bias For Identifying Topoisomerase Mutations in Ciprofloxacin Resistant Escherichia coli Using PCR and Future Prospects with Other Bacterial Genera: A Pilot Study. Advances in Biological Chemistry, 2, 366-371. https://doi.org/10.4236/abc.2012.24045

[45] Falodun, O.I. and Adekanmbi, A.O. (2016) Antibiogram of Escherichia coli and Pseudomonas Strains Isolated from Wastewater Generated by an Abattoir as It Journeys into a Receiving River. Advances in Microbiology, 6, 303-309. https://doi.org/10.4236/aim.2016.64029

[46] Shatalov, A. (2015) Prevalence and Antibiotic Resistance Pattern of Escherichia coli and Klebsiella pneumonia in Urine Tract Infections at the La Paz Medical Center, Malabo, Equatorial Guinea. Open Journal of Medical Microbiology, 5, 177-183. https://doi.org/10.4236/ojmm.2015.54022

Submit or recommend next manuscript to SCIRP and we will provide best service for you:

Accepting pre-submission inquiries through Email, Facebook, LinkedIn, Twitter, etc. A wide selection of journals (inclusive of 9 subjects, more than 200 journals)

Providing 24-hour high-quality service

User-friendly online submission system

Fair and swift peer-review system

Efficient typesetting and proofreading procedure

Display of the result of downloads and visits, as well as the number of cited articles Maximum dissemination of your research work

Submit your manuscript at: http://papersubmission.scirp.org/

Or contact abc@scirp.org 